\title{
Deformability of the masonry subjected to shearing due to vertical displacements
}

\author{
Adam Piekarczyk \\ Department of Building Structures; Faculty of Civil Engineering; Silesian University of Technology; \\ 5 Akademicka Street, 44-100 Gliwice, Poland; \\ Adam.Piekarczyk@polsl.pl (DD000-0002-5790-9560
}

\begin{abstract}
The paper presents the results of tests of masonry specimens subjected to vertical displacement, with limited deformations in a direction parallel to the masonry bed joints (horizontally) and additionally compressed in the direction perpendicular to the bed joints (vertically). Specimens in the form of fragments of masonry walls were made of solid ceramic brick and AAC blocks. Studies have shown that the nature of the relationship between wall deformation angles and shear stresses caused by vertical displacements depends on the values of accompanying compressive stresses normal to the plane of the masonry bed joints. Compressive stresses have a positive effect on the load-bearing capacity and crack resistance of this type of masonry walls and the angles of deformation occurring at the moment of cracking. The dependence of the transverse stiffness modulus on the value of shear stresses is strongly non-linear, but with increasing shear stresses, it stabilises at a certain level independent of the values of compressive stresses associated with shear.
\end{abstract}

Keywords: vertical shear, vertical wall displacement, transverse stiffness, shear deformation angle

\section{Introduction}

Vertical displacements of masonry walls may result from deformations of the structures on which they are directly supported, i.e. deflections of ceiling members, floors, lintel beams and foundations or displacements transferred from other elements adjacent to these walls, e.g. transverse walls and columns.

Uneven displacements of foundations and floors may be the effect of improper preparation of the subsoil [1]-[9] resulting from inadequate or uneven compaction, changes in water regimes due to drainage, land quality improvement, deep excavations in the vicinity, swelling or shrinkage of the subsoil caused by vegetation, displacement of expansive soils, soil leaching during plumbing or rainfall installations failure, loss of soil stability. Additional displacements of the subsoil may also be the result of erecting new buildings next to existing 
ones, compaction of the soil and increasing loads due to vehicle traffic or other dynamic loads. Underground mining exploitation also causes the formation of continuous and discontinuous deformations on the land surface.

In masonry walls subjected to the influences mentioned above, usually a complex stress state occurs resulting not only from shear caused by vertical displacements. Additionally, the value and direction of the principal stresses causing cracking and failure are also affected by the limited freedom of deformation in the horizontal direction by the adjacent structural members and, in case of load-bearing walls, vertical compressive stresses transmitted to the wall from the upper storeys.

Research on unreinforced and reinforced masonry shear walls due to vertical displacements, among other research problems, has been conducted at the Civil Engineering Faculty of the Silesian University of Technology for over 20 years and published, among others, in works [1], [3], [5], [10]-[22]. The described research problem is rarely analysed experimentally and theoretically. The author is known only to a few foreign publications, which are quite loosely related to the subject presented here. Subject-related studies were described in reports from foreign researches [23]-[25]. On the one hand, it proves the originality of the presented research, and on the other hand, it makes it difficult to compare the results of the tests with the results from other research centres.

\section{Specimens and test stand}

\subsection{Materials and specimens}

The tests were carried out on specimens made of solid ceramic bricks and autoclaved aerated concrete blocks (AAC). The walls made of ceramic bricks had bed joints of normal thickness, nominally equal to $10 \mathrm{~mm}$, while the specimens of AAC had thin bed joints with a nominal thickness of $3 \mathrm{~mm}$ and unfilled head joints.

For ceramic brick specimens, masonry units with mean compressive strength $f_{\mathrm{B}}=28.8 \mathrm{~N} / \mathrm{mm}^{2}$ and normalised strength $f_{\mathrm{b}}=23.3 \mathrm{~N} / \mathrm{mm}^{2}$ determined in accordance with PN-EN 772-1 [26] and with a coefficient of variation equal to $6.4 \%$ were used. A prescribed cement-lime mortar was used with a volume components ratio 1:1:6 (cement:lime:sand) with mean compressive strength determined according to PN-EN 998-2 [27] standard equal to $f_{\mathrm{m}}=9.7 \mathrm{~N} / \mathrm{mm}^{2}$ with a coefficient of variation of $10.0 \%$

AAC blocks with a nominal volume density of $500 \mathrm{~kg} / \mathrm{m}^{3}$ had a mean compressive strength of $2.7 \mathrm{~N} / \mathrm{mm}^{2}$ and normalised strength according to [26] $f_{\mathrm{b}}=3.1 \mathrm{~N} / \mathrm{mm}^{2}$ with a coefficient of variation of $7.9 \%$. The system prescribed mortar for thin joins bonding AAC blocks had a mean compressive strength according to [27] $f_{\mathrm{m}}=18.8 \mathrm{~N} / \mathrm{mm}^{2}$ with a coefficient of variation of $9.6 \%$.

The dimensions of the specimens are shown in Fig. 1. The thickness of the specimens made of ceramic bricks was $25 \mathrm{~cm}$, whereas of AAC blocks $24 \mathrm{~cm}$. 


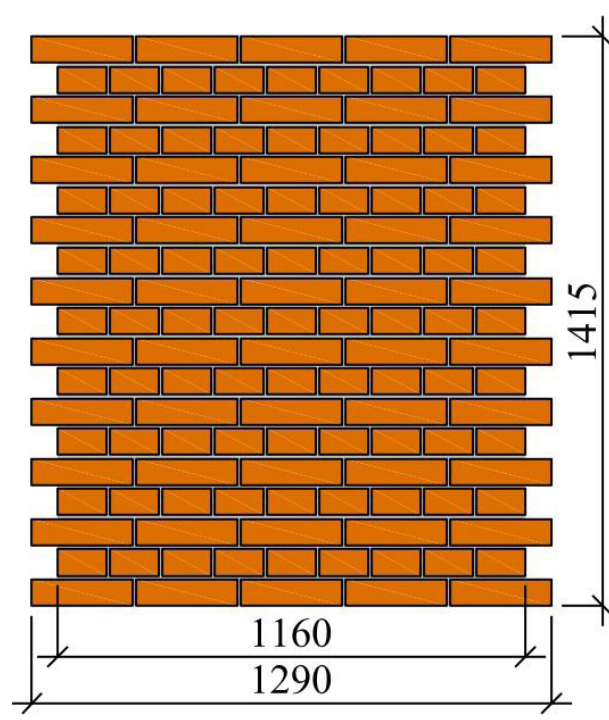

a)

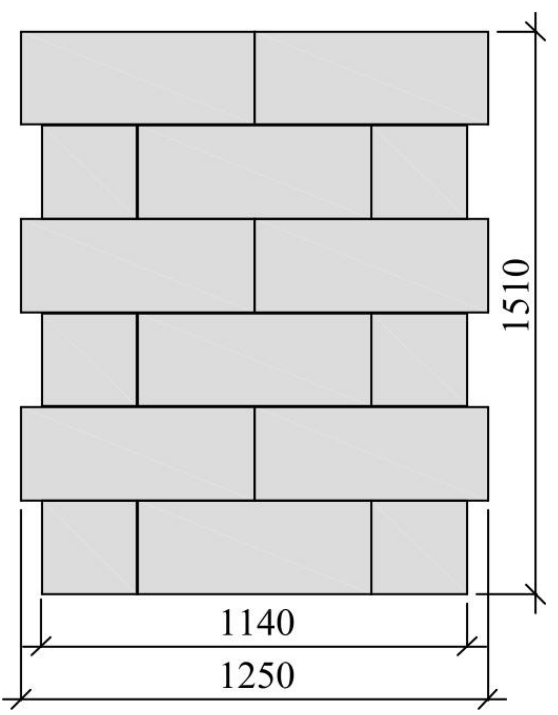

b)

Fig. 1. Specimens used in the tests made of: a) solid ceramic bricks, b) AAC blocks. Source: own study

Ten specimens made of ceramic bricks and five specimens made of AAC blocks were tested. The specimens were divided into groups depending on the values of compressive stresses normal to the masonry bed joints plane $\sigma_{\mathrm{c}}$ that accompanied the vertical displacements and shear in this direction. The specimens were tested without the participation of $\sigma_{\mathrm{c}}$ stress and at four compressive stress values in the case of ceramic bricks specimens and with $\sigma_{\mathrm{c}}=0.9 \mathrm{~N} / \mathrm{mm}^{2}$ for AAC blocks specimens. Tab. 1 lists individual test series with their symbols, values of compressive stresses accompanying vertical displacements and a total number of specimens.

Table 1. Tests programme. Source: own study

\begin{tabular}{|c|c|}
\hline \multicolumn{2}{|c|}{ Ceramic solid bricks masonry } \\
\hline Specimen & $\begin{array}{l}\text { Compressive stress } \sigma_{\mathrm{c}} \text {, } \\
\mathrm{N} / \mathrm{mm}^{2}\end{array}$ \\
\hline CB-00/1 & \multirow{2}{*}{0} \\
\hline CB-00/2 & \\
\hline CB-03/1 & \multirow{2}{*}{0.3} \\
\hline CB- $03 / 2$ & \\
\hline CB-06/1 & \multirow{2}{*}{0.6} \\
\hline CB- $06 / 2$ & \\
\hline CB-09/1 & \multirow{2}{*}{0.9} \\
\hline CB-09/2 & \\
\hline CB-15/1 & \multirow{2}{*}{1.5} \\
\hline CB-15/2 & \\
\hline
\end{tabular}

\begin{tabular}{|c|c|}
\hline \multicolumn{2}{|c|}{ AAC blocks masonry } \\
\hline Specimen & $\begin{array}{l}\text { Compressive stress } \sigma_{\mathrm{c}}, \\
\mathrm{N} / \mathrm{mm}^{2}\end{array}$ \\
\hline $\mathrm{AAC}-00 / 1$ & \multirow{3}{*}{0} \\
\hline $\mathrm{AAC}-00 / 2$ & \\
\hline AAC $-00 / 3$ & \\
\hline AAC-09/1 & \multirow{2}{*}{0.9} \\
\hline AAC- $09 / 2$ & \\
\hline
\end{tabular}




\subsection{Test stand and testing technique}

The tests were carried out in the specially designated test stand shown in Fig. 2. The main elements of the test stand were two external columns, the internal column through which the vertical displacements were produced by $F$ force, horizontal ties transferring $S$ forces, resisting members transmitting vertical $R$ and horizontal $H$ reactions and members for developing vertical compressive stress $\sigma_{\mathrm{c}}$ using $N_{\mathrm{c}}$ forces. Photograph of Fig. 3 shows the specimen monolithised with columns and prepared for a test.

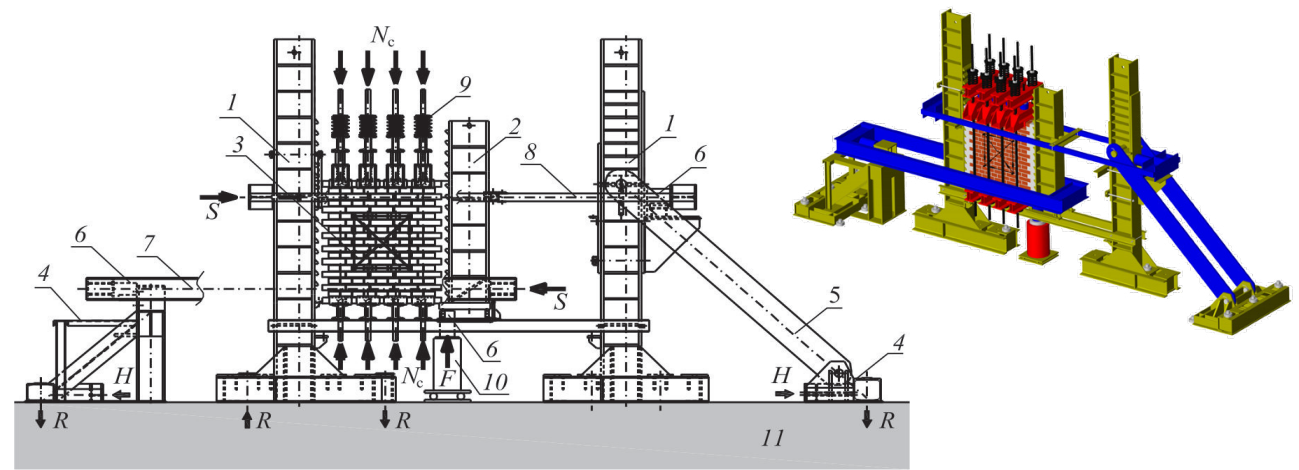

Fig. 2. Test stand: 1 - external column, 2 - internal column, 3 - masonry specimen, 4 - resisting member, 5 - tension member, 6 - load cell, 7 - lower tie, 8 - upper tie, 9 - members inducing compressive stresses, 10 - hydraulic jack, 11 - laboratory floor. Source: own study

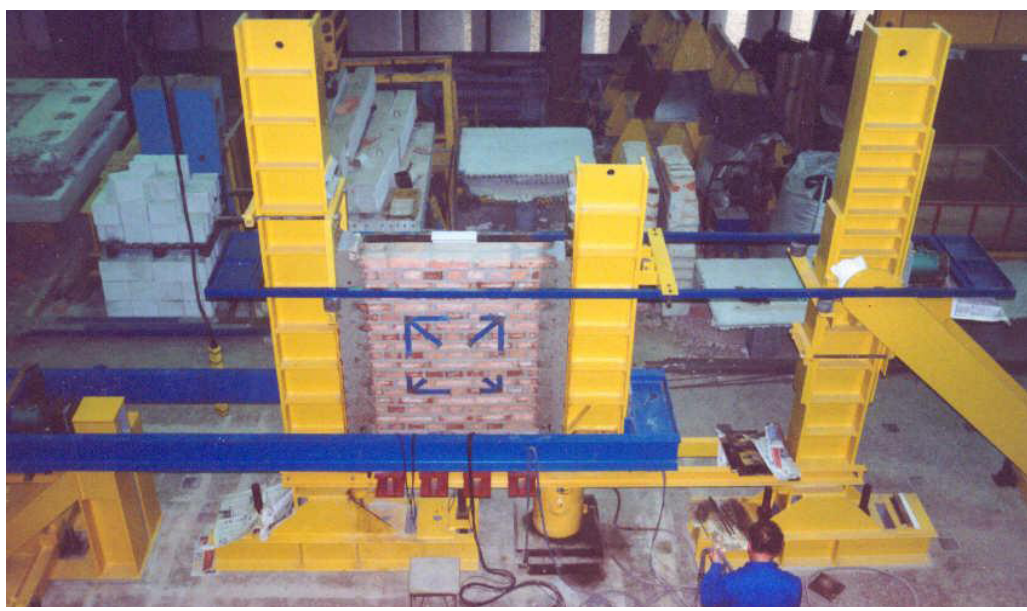

Fig. 3. Specimen made of ceramic bricks prepared for testing. Source: own study

The masonry specimen was monolithised with an external and internal column using concrete containing early strength gain Portland cement. Vertical displacements were induced by force $F$ using a hydraulic cylinder and transferred to the specimen via an internal column equipped with dowels. Force $F$ was measured by a strain gauge load cell. The vertical reaction was transferred from the specimen to the outer column also having steel dowels and further to the laboratory floor. Horizontal S-reactions were measured by means load cells, transmitted to resisting members and to the laboratory floor. Compressive stress normal to the plane of the 
masonry bed joints $\sigma_{\mathrm{c}}$ was induced by a system of three (AAC) or four (CB) pairs of $45 \mathrm{~mm}$ diameter steel tendons under $N_{\mathrm{c}}$ force and equipped with springs compensating the influence of vertical wall displacements on the value and distribution of $\sigma_{\mathrm{c}}$ stress. Fig. 4 schematically shows the loads to the specimen was subjected to during the test and the stresses affecting the central area of the wall outside the zone of the disturbance of stress distribution.

a)

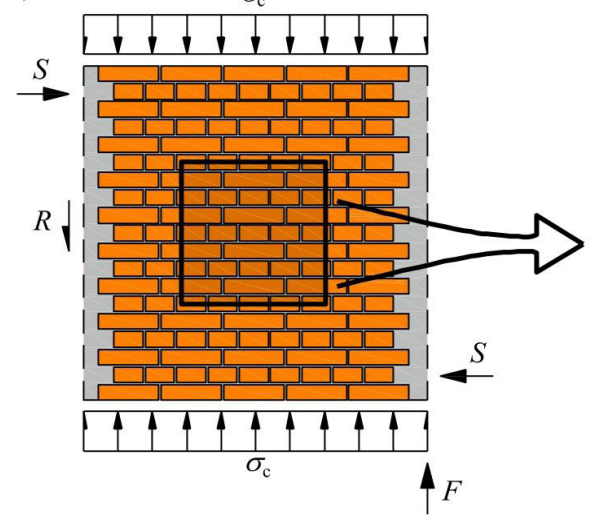

b)

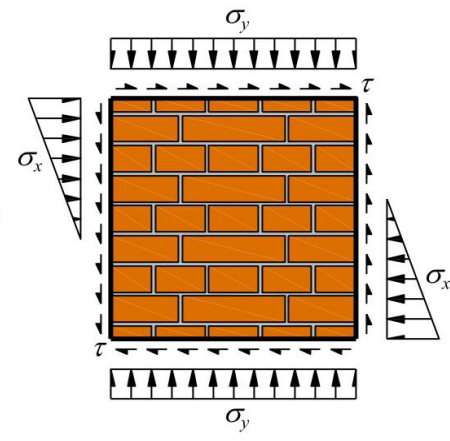

Fig. 4. Diagram of: a) external loads acting on the specimen, b) stresses in the central part of the wall. Source: own study

In addition to the force values, changes in the mutual position of four measuring points on the wall surface on both specimen sides were recorded during the test. Mutual dislocations of these points were determined based on the change in the length of the measurement bases, which formed a square measurement system on the faces of the specimen with a side length equal to $600 \mathrm{~mm}$ - Fig. 5a. Displacements were recorded using six transducers for each face of the specimen with a measurement accuracy of $0.002 \mathrm{~mm}$. Values of wall deformation angles were determined on the basis of changes in the length of measurement bases according to the diagram shown in Fig. 5 b. For example, the angle $\theta_{1}$ was calculated from the Eq. 1, in which $a_{\mathrm{i}}, b_{\mathrm{i}}$ and $c_{\mathrm{i}}$ are the lengths of the sides of the respective triangle at the $i$-th load level.

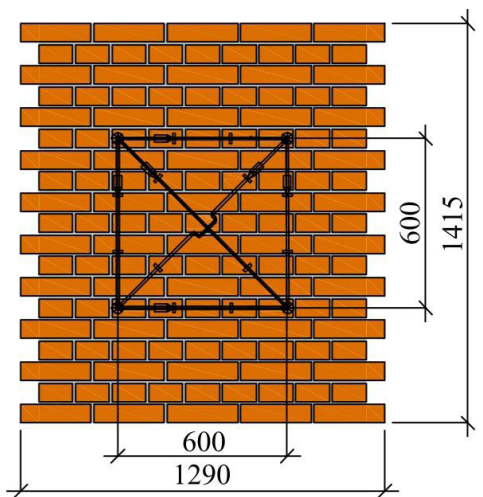

a)

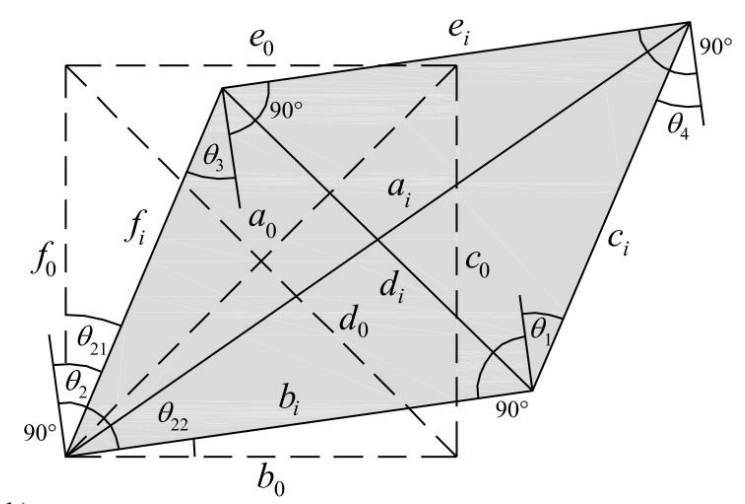

b)

Fig. 5. Method of measuring deformations of specimens: a) square system of measuring bases equipped with displacement transducers, b) determination of deformation angles. Source: own study 


$$
\theta_{1}=\arcsin \left(\frac{a_{\mathrm{i}}^{2}-b_{\mathrm{i}}^{2}-c_{\mathrm{i}}^{2}}{2 b_{\mathrm{i}} c_{\mathrm{i}}}\right)
$$

The tests were carried out with a monotonic load increase until failure, i.e. a state at which it was not possible to obtain a higher value of the vertical force $F$.

\section{Test results and discussion}

Tab. 2 summarises the obtained test results, i.e. the values of shear stress accompanying the occurrence of the first crack $\tau_{\mathrm{cr}}$ and the corresponding mean value $\tau_{\mathrm{cr}, \mathrm{m}}$, ultimate shear stresses $\tau_{\mathrm{u}}$ and $\tau_{\mathrm{u}, \mathrm{mv}}$, the ratio of mean ultimate shear stresses to shear stresses at the moment of cracking $\tau_{\mathrm{u}, \mathrm{mv}} / \tau_{\mathrm{cr}, \mathrm{mv}}$, deformation angles determined at the occurrence of cracks and accompanying the ultimate load obtained, $\theta_{\text {cr.mv }}$ and $\theta_{\text {u.mv }}$ respectively, the mean values of these angles $\theta_{\text {cr.mv }}$ and $\theta_{\text {u.mv }}$, the ratio $\theta_{\text {u.mv }} / \theta_{\text {cr.mv }}$, as well as the values of the transverse stiffness modulus $D_{\text {cr }}$ determined on the basis of shear stresses and angles of deformation obtained at the moment of masonry cracking and corresponding mean values $D_{\text {cr.mv }}$.

The shear stress $\tau_{\mathrm{i}}$ was determined as averaged at the height of the specimen by dividing the force $F_{\mathrm{i}}$ causing vertical displacements by the vertical cross-sectional area of the wall $A_{\mathrm{v}}$. The transverse stiffness modulus $D_{\mathrm{i}}$ was calculated as the quotient of the shear stress $\tau_{\mathrm{i}}$ and the corresponding deformation angle $\theta_{\mathrm{i}}$ :

$$
D_{\mathrm{i}}=\frac{\tau_{\mathrm{i}}}{\theta_{\mathrm{i}}}
$$


Table 2. Basic test results. Source: own study

Ceramic solid bricks masonry

\begin{tabular}{|c|c|c|c|c|c|c|c|}
\hline Specimen & $\begin{array}{l}\sigma_{\mathrm{c}} \\
\mathrm{N} / \mathrm{mm}^{2}\end{array}$ & $\begin{array}{l}\tau_{\mathrm{cr}} \\
\mathrm{N} / \mathrm{mm}^{2}\end{array}$ & $\begin{array}{l}\tau_{\text {cr.mv }}, \\
\mathrm{N} / \mathrm{mm}^{2}\end{array}$ & $\begin{array}{l}\tau_{\mathrm{u}}, \\
\mathrm{N} / \mathrm{mm}^{2}\end{array}$ & $\begin{array}{l}\tau_{\mathrm{u} . \mathrm{mv}}, \\
\mathrm{N} / \mathrm{mm}^{2}\end{array}$ & $\tau_{\text {u.mv }} / \tau_{\text {cr.mv }}$ & $\begin{array}{l}\theta_{\mathrm{cr}} \\
\mathrm{mm} / \mathrm{m}\end{array}$ \\
\hline CB-00/1 & \multirow{2}{*}{0} & 0.568 & \multirow{2}{*}{0.582} & 0.683 & \multirow{2}{*}{0.656} & \multirow{2}{*}{1.13} & 0.378 \\
\hline CB-00/2 & & 0.569 & & 0.628 & & & 0.344 \\
\hline CB-03/1 & \multirow{2}{*}{0.3} & 0.776 & \multirow{2}{*}{0.799} & 0.942 & \multirow{2}{*}{0.940} & \multirow{2}{*}{1.18} & 0.386 \\
\hline CB-03/2 & & 0.822 & & 0.937 & & & 0.362 \\
\hline CB-06/1 & \multirow{2}{*}{0.6} & 0.905 & \multirow{2}{*}{0.919} & 1.24 & \multirow{2}{*}{1.21} & \multirow{2}{*}{1.32} & 0.545 \\
\hline CB-06/2 & & 0.933 & & 1.18 & & & 0.576 \\
\hline CB-09/1 & \multirow{2}{*}{0.9} & 1.16 & \multirow{2}{*}{1.11} & 1.35 & \multirow{2}{*}{1.34} & \multirow{2}{*}{1.21} & 0.602 \\
\hline CB-09/2 & & 1.05 & & 1.33 & & & 0.743 \\
\hline CB-15/1 & \multirow{2}{*}{1.5} & 1.27 & \multirow{2}{*}{-1.30} & 1.67 & \multirow{2}{*}{1.70} & \multirow{2}{*}{1.31} & 0.818 \\
\hline CB-15/2 & & 1.33 & & 1.73 & & & 0.934 \\
\hline Specimen & $\begin{array}{l}\sigma_{\mathrm{c}} \\
\mathrm{N} / \mathrm{mm}^{2}\end{array}$ & $\begin{array}{l}\theta_{\text {cr. } \mathrm{v}} \\
\mathrm{mm} / \mathrm{m}\end{array}$ & $\begin{array}{l}\theta_{\mathrm{u}}, \\
\mathrm{mm} / \mathrm{m}\end{array}$ & $\begin{array}{l}\theta_{\text {u.mv }}, \\
\mathrm{mm} / \mathrm{m}\end{array}$ & $\theta_{\text {u.mv }} / \theta_{\text {cr.mv }}$ & $\begin{array}{l}D_{\mathrm{cr}}, \\
\mathrm{N} / \mathrm{mm}^{2}\end{array}$ & $\begin{array}{l}D_{\text {cr.mv }}, \\
\mathrm{N} / \mathrm{mm}^{2}\end{array}$ \\
\hline CB-00/1 & \multirow{2}{*}{0} & \multirow{2}{*}{0.361} & 5.83 & \multirow{2}{*}{-3.11} & \multirow{2}{*}{8.60} & 1503 & \multirow{2}{*}{1618} \\
\hline CB-00/2 & & & 0.381 & & & 1733 & \\
\hline CB-03/1 & \multirow{2}{*}{0.3} & \multirow{2}{*}{0.374} & 0.533 & \multirow{2}{*}{0.490} & 131 & 2010 & 2141 \\
\hline CB-03/2 & & & 0.446 & & 1.31 & 2271 & 2141 \\
\hline CB-06/1 & & & 6.90 & & & 1661 & \\
\hline CB-06/2 & 0.6 & 0.561 & 3.54 & 5.22 & 9.31 & 1620 & 1640 \\
\hline CB-09/1 & & & 5.43 & & & 1927 & \\
\hline CB-09/2 & 0.9 & 0.673 & 4.12 & 4.78 & 7.10 & 1413 & 1670 \\
\hline CB-15/1 & & 0876 & 9.14 & 905 & 103 & 1553 & \\
\hline CB-15/2 & 1.5 & $0.8 / 6$ & 8.96 & 9.05 & 10.3 & 1424 & 1488 \\
\hline AAC block & nasonry & & & & & & \\
\hline Specimen & $\begin{array}{l}\sigma_{\mathrm{c}} \\
\mathrm{N} / \mathrm{mm}^{2}\end{array}$ & $\begin{array}{l}\tau_{\mathrm{cr}} \\
\mathrm{N} / \mathrm{mm}^{2}\end{array}$ & $\begin{array}{l}\tau_{\text {cr.mv }} \\
\mathrm{N} / \mathrm{mm}^{2}\end{array}$ & $\begin{array}{l}\tau_{\mathrm{u}}, \\
\mathrm{N} / \mathrm{mm}^{2}\end{array}$ & $\begin{array}{l}\tau_{\mathrm{u} . \mathrm{mv}} \\
\mathrm{N} / \mathrm{mm}^{2}\end{array}$ & $\tau_{\text {u.mv }} / \tau_{\text {cr.mv }}$ & $\begin{array}{l}\theta_{\mathrm{cr}} \\
\mathrm{mm} / \mathrm{m}\end{array}$ \\
\hline AAC-00/1 & & 0.181 & & 0.181 & & & 0.273 \\
\hline AAC- $00 / 2$ & 0 & 0.188 & 0.177 & 0.188 & 0.177 & 1.0 & 0.323 \\
\hline $\mathrm{AAC}-00 / 3$ & & 0.163 & & 0.163 & & & 0.336 \\
\hline AAC-09/1 & & 0.282 & & 0.505 & & & 0.589 \\
\hline AAC- $09 / 2$ & 0.9 & 0.385 & 0.334 & 0.526 & 0.516 & 1.55 & 0.872 \\
\hline Specimen & $\begin{array}{l}\sigma_{\mathrm{c}} \\
\mathrm{N} / \mathrm{mm}^{2}\end{array}$ & $\begin{array}{l}\theta_{\text {cr.mv }} \\
\mathrm{mm} / \mathrm{m}\end{array}$ & $\begin{array}{l}\theta_{\mathrm{u}}, \\
\mathrm{mm} / \mathrm{m}\end{array}$ & $\begin{array}{l}\theta_{\text {u.mv }} \\
\mathrm{mm} / \mathrm{m}\end{array}$ & $\theta_{\text {u.mv }} / \theta_{\text {cr.mv }}$ & $\begin{array}{l}D_{\mathrm{cr}} \\
\mathrm{N} / \mathrm{mm}^{2}\end{array}$ & $\begin{array}{l}D_{\text {cr.mv }}, \\
\mathrm{N} / \mathrm{mm}^{2}\end{array}$ \\
\hline AAC-00/1 & & & 0.273 & & & 663 & \\
\hline AAC- $00 / 2$ & 0 & 0.311 & 0.323 & 0.311 & 1.0 & 582 & 577 \\
\hline AAC- $00 / 3$ & & & 0.337 & & & 485 & \\
\hline AAC-09/1 & & & 2.61 & & & 479 & \\
\hline AAC-09/2 & 0.9 & 0.731 & 2.76 & 2.69 & 3.68 & 442 & 460 \\
\hline
\end{tabular}

Fig. 6 shows the relationship between shear stresses $\tau_{\mathrm{i}}$ and deformation angles $\theta_{\mathrm{i}}$ at various values of accompanying normal compressive stress $\sigma_{\mathrm{c}}$ for specimens made of ceramic bricks and AAC blocks. The graph in Fig. 7 shows the changes in the transverse stiffness modulus $D_{\mathrm{i}}$ depending on the stress value $\tau_{\mathrm{i}}$ in the range from 0 to $\tau_{\mathrm{cr}}$ at different compressive stress $\sigma_{\mathrm{c}}$.

In Fig. 6, the positive effect of the compressive stress $\sigma_{\mathrm{c}}$ on the values of ultimate shear stress $\tau_{\mathrm{u}}$ is visible. The ratio of mean stress $\tau_{\mathrm{u} \text {.mv }}$ obtained at stress $\sigma_{\mathrm{c}}=1.5 \mathrm{~N} / \mathrm{mm}^{2}$ to the ultimate shear stress in the case of the non-compression test was 2.59 . There is also a visible change 
in the nature of the wall behaviour after cracking. In the case of specimens tested without the compressive stress $\sigma_{\mathrm{c}}$ and ceramic brick walls sheared at $\sigma_{\mathrm{c}}=0.3 \mathrm{~N} / \mathrm{mm}^{2}$, it can be observed that after cracking, the deformation angle increases sharply while shear stress decreases. At higher values of compressive stress $\sigma_{c}$, the quasi-plastic nature of the wall behaviour is visible. It consists in the fact that after cracking, the specimens are able to carry loads higher than those that caused the cracking, i.e. it is strengthened, while the deformation increases significantly.

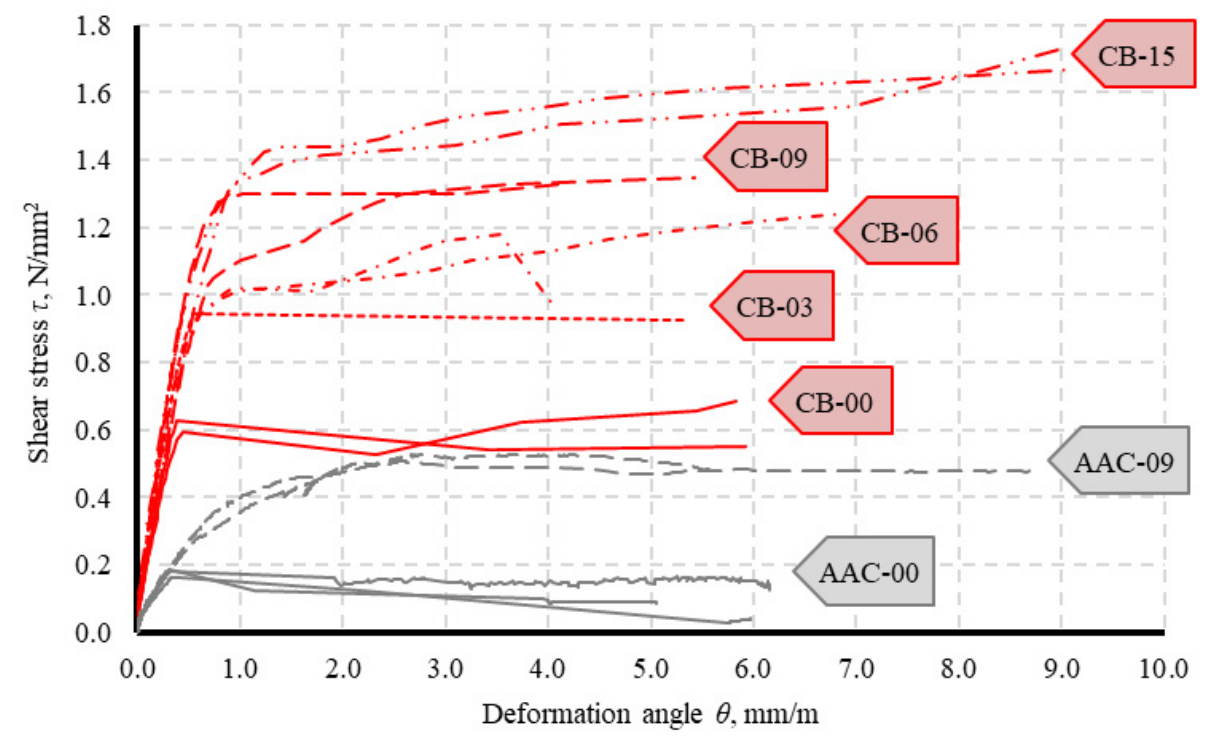

Fig. 6. Dependence of deformation angles $\theta_{\mathrm{i}}$ on the value of stresses $\tau_{\mathrm{i}}$. Source: own study

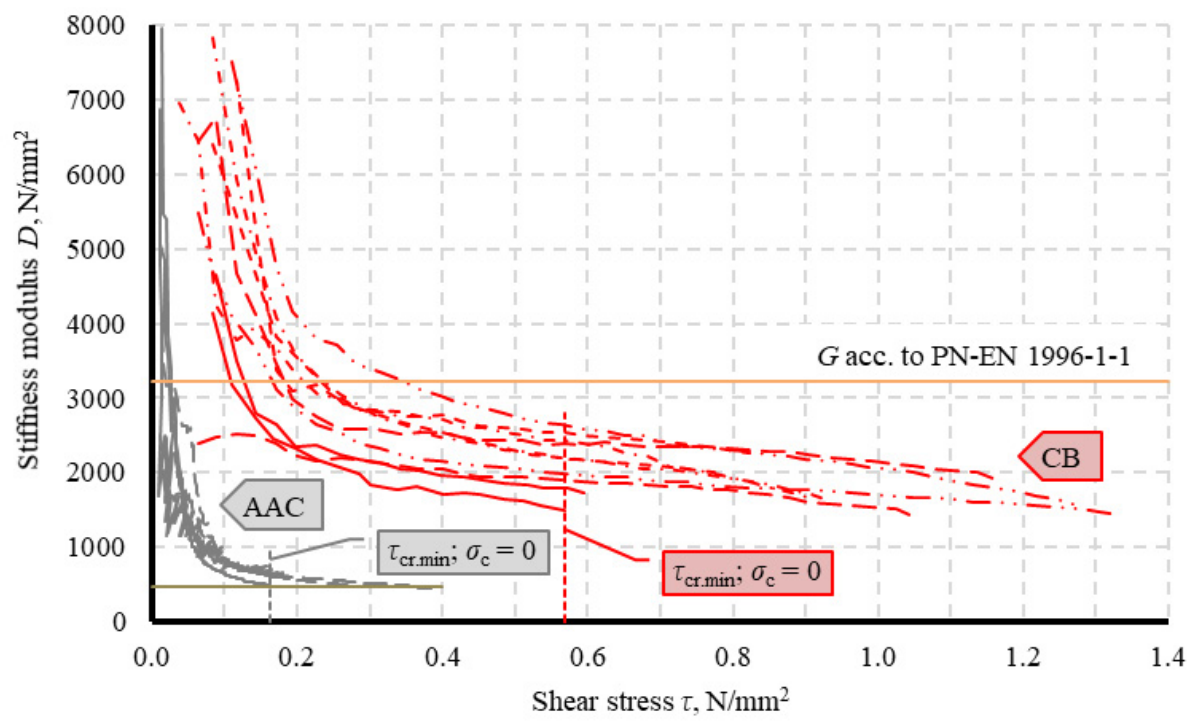

Fig. 7. Changes in the value of transverse stiffness modulus $D_{\mathrm{i}}$ depending on the shear stress $\tau_{\mathrm{i}}$ in the range $\tau_{\mathrm{i}}=0-\tau_{\mathrm{cr}}$. Source: own study 
There is also a relationship between the values of compressive stress $\sigma_{\mathrm{c}}$ and the shear stresses $\tau_{\text {cr }}$ and angles $\theta_{\text {cr }}$ obtained at the moment of the first crack appearance. Fig. 8a shows an increase in the stress $\tau_{\mathrm{cr}}$ as the compressive stress increases. The absolute increase in shear stress value was higher for brick walls, the difference between $\tau_{\text {crmv }}$ obtained at stress $\sigma_{\mathrm{c}}=0.9 \mathrm{~N} / \mathrm{mm}^{2}$ and $\sigma_{\mathrm{c}}=0$ was 0.528 and $0.157 \mathrm{~N} / \mathrm{mm}^{2}$, respectively, for ceramic brick and AAC block walls. However, the relative increase understood as the quotient of the stress difference mentioned above and stress values $\tau_{\text {cr.mv }}$ at $\sigma_{\mathrm{c}}=0$ was about 0.90 for walls made of both types of masonry units.

Similarly, Fig. $8 \mathrm{~b}$ shows the effect of stress $\sigma_{\mathrm{c}}$ on the obtained deformation angles at the moment of masonry cracking $\theta_{\mathrm{cr}}$. The wall was cracked with larger deformation angles, the higher the compressive stress values were. The relative increase in angles $\theta_{\mathrm{cr}}$ obtained at $\sigma_{\mathrm{c}}=0$ and $0.9 \mathrm{~N} / \mathrm{mm}^{2}$ was about 0.86 for ceramic brick walls and 1.35 for specimens made of AAC blocks.

a)

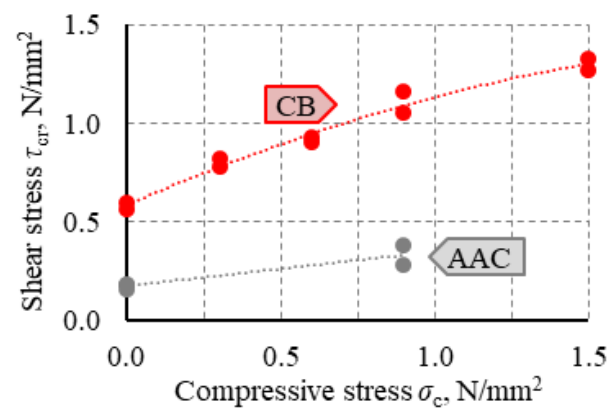

b)

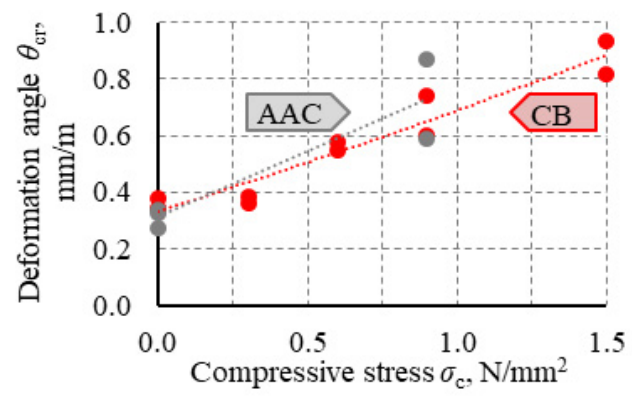

Fig. 8. The effect of compressive stress $\sigma_{\mathrm{c}}$ on the accompanying formation of the first cracking: a) shear stresses $\tau_{\mathrm{cr}}$, b) deformation angles $\theta_{\mathrm{cr}}$. Source: own study

The dependence of the transverse stiffness modulus $D_{\mathrm{i}}$ on the shear stress $\tau_{\mathrm{i}}$, as can be seen in Fig. 7, is strongly non-linear. Initially, at low stress $\tau_{\mathrm{i}}$, the stiffness decreases sharply, after which it undergoes relative stabilisation, but still shows a tendency to decrease. A much higher lateral rigidity of the walls made of ceramic bricks is visible. In the case of brick specimens, it is also possible to observe higher stiffness of the walls, which were tested with the simultaneous action of compressive stress $\sigma_{c}$, which was not found in the case of specimens made of AAC blocks.

On the graph shown in Fig. 7, for illustrative purposes, the values of the shear modulus $G$ are depicted as a horizontal solid line. However, it should be remembered that shear modulus $G$ is a material feature of the body subjected to deformations, which results in only a change in shape, without changing the volume, i.e. in the so-called simple shear case. Therefore, $G$ modulus and the transverse stiffness modulus $D$ discussed here are not the same parameters. Modulus $\mathrm{G}$ was determined for a wall made of both types of masonry in accordance with PN-EN 1996-1-1 [26], i.e.:

$$
G=0.4 E,
$$

where $E$ is the modulus of elasticity determined according to the standard [26] as the characteristic compressive strength of the masonry $f_{\mathrm{k}}$ multiplied by the masonry elasticity coefficient 
$K_{\mathrm{E}}$ equal to 1000 or 600 , respectively for ceramic brick and AAC block masonry. Masonry strength $f_{\mathrm{k}}$ was also calculated using standard relationships based on normalised compressive strength of masonry units and, in the case masonry made of ceramic bricks, mean compressive strength of mortar. Modulus $G$ was similar in value to the transverse stiffness modulus $D_{\text {cr }}$ in the case of walls made of AAC blocks. The transverse stiffnesses of the brick walls after falling to relatively stable values, not subjected to rapid changes as the shear stress increases were lower than the value of calculated shear modulus $G$ (see Fig. 7).

Fig. 9a is a graph depicting the values of transverse stiffness modulus obtained on the basis of the stresses and deformation angles recorded at the moment of masonry cracking $D_{\mathrm{cr}}$. This modulus does not change significantly with a change in the value of compressive stress $\sigma_{\mathrm{c}}$, although a slight tendency to decrease with increasing $\sigma_{\mathrm{c}}$ stress can be observed here. The values of $D_{\mathrm{cr}}$ modulus was determined based on the shear stress $\tau_{\mathrm{cr}}$ and angles $\theta_{\mathrm{cr}}$, which increased with the growth of the compressive stress $\sigma_{\mathrm{c}}$, therefore they do not correctly show the effect of this compression on transverse stiffness modulus $D$. For this reason Fig. $9 \mathrm{~b}$ shows the values of $D_{\mathrm{i}}$ modulus determined at the smallest shear stress $\tau_{\text {cr.min }}$ occurring at the moment of masonry cracking of walls tested without compression $\left(\sigma_{\mathrm{c}}=0\right)-$ see Fig. 7, which were 0.163 and $0.568 \mathrm{~N} / \mathrm{mm}^{2}$ in the case of specimens made of AAC blocks and ceramic bricks, respectively. As can be seen in Fig. 9b graph, the stiffness principally did not depend on the compressive stress value $\sigma_{\mathrm{c}}$. However, there is an increase in the mean stiffness of ceramic brick walls tested at $\sigma_{\mathrm{c}} \neq 0$ by 30 to $45 \%$ compared to the stiffness specified at $\sigma_{\mathrm{c}}=0$. For walls made of AAC blocks, this increase was only $4 \%$.

Fig. 10 shows the pattern of the cracks of masonry specimens observed at failure for the maximum accompanying compressive stress $\sigma_{\mathrm{c}}$ and without compression. In the case of specimens made of ceramic bricks tested at $\sigma_{\mathrm{c}}=0$ (Fig. 10a), there are much fewer cracks, basically it is a single bifurcating crack, which mostly runs at the interface of masonry units and mortar. Stress $\sigma_{\mathrm{c}}=1.5 \mathrm{~N} / \mathrm{mm}^{2}$ changed the way the masonry cracked (Fig. 10b); there are more cracks, and they run mainly through masonry units. Specimens made of AAC blocks tested without compressive stresses failed as it is shown in Fig. 10c, i.e. a single diagonal crack was created, which due to the proportions of masonry units mainly ran diagonally through the blocks. In the case of specimens tested at stress $\sigma_{\mathrm{c}}=0.9 \mathrm{~N} / \mathrm{mm}^{2}$, many cracks and detachments of material appeared on the outer surface of the masonry blocks (Fig. 10d). The direction of the cracks was much closer to vertical.

a)

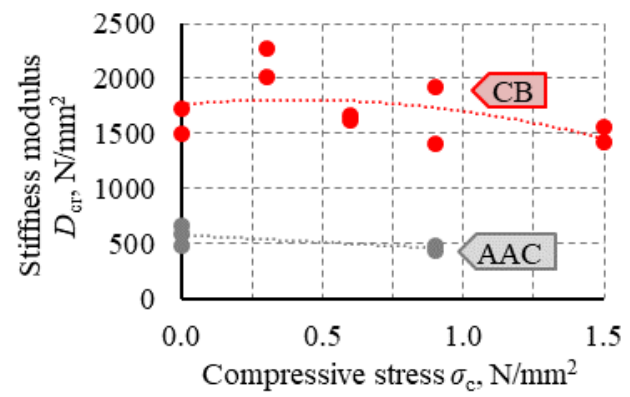

b)

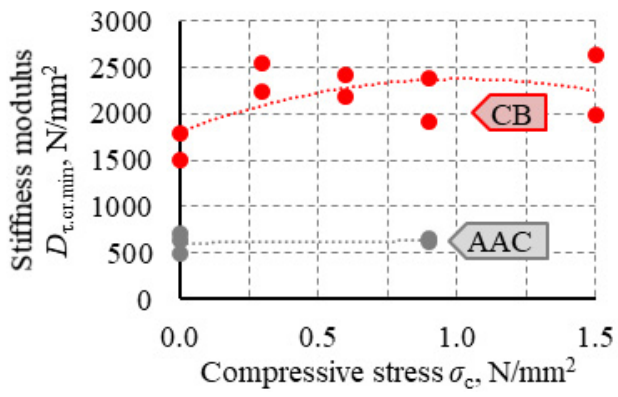

Fig. 9. Influence of compressive stress $\sigma_{c}$ on the values of transverse stiffness modulus: a) at shear stresses $\tau_{\mathrm{cr}}$ proper for each specimen, b) at shear stresses $\tau_{\mathrm{cr}}$ lowest in the group of specimens made of bricks and AAC blocks. Source: own study 
a)

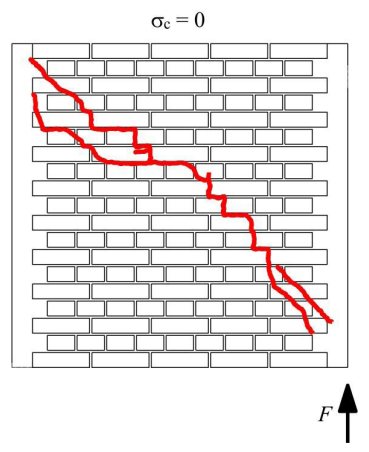

c)

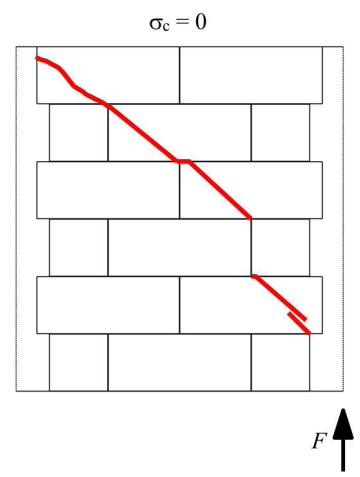

b)

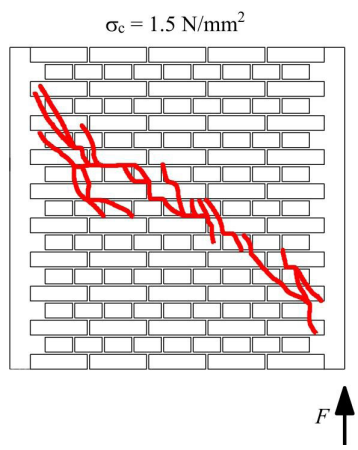

d)

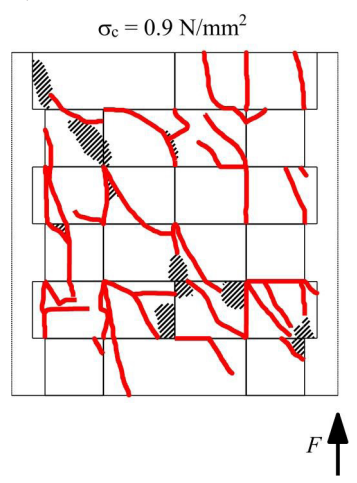

Fig. 10. Cracks pattern at the failure of masonry specimens made of: a), b) ceramic bricks, c), d) AAC blocks. Source: own study

\section{Conclusions}

Based on the tests carried out in the scope described above, the following conclusions can be made:

- The nature of the dependence of the deformation angle $\theta_{\mathrm{i}}$ on the shear stress $\tau_{\mathrm{i}}$ was determined by the values of compressive stresses normal to the plane of masonry bed joints $\sigma_{\mathrm{c}}$. At low values of $\sigma_{\mathrm{c}}$ or in its absence, the brittle nature failure was observed. At stresses $\sigma_{\mathrm{c}} \geq 0.6 \mathrm{~N} / \mathrm{mm}^{2}$, the quasi-plastic behaviour was visible with hardening in the phase after masonry cracking;

- The increase in compressive stress value $\sigma_{\mathrm{c}}$ meant that the first crack occurred at higher values of shear stress $\tau_{\mathrm{cr}}$ and deformation angle $\theta_{\mathrm{cr}}$;

- Compressive stresses $\sigma_{\mathrm{c}}$ had a positive effect on the load-bearing capacity of masonry sheared due to vertical displacements;

- The dependence of the transverse stiffness modulus on the value of shear stress was strongly non-linear. After the initial rapid decrease in stiffness, its further degradation was significantly slowed down;

- The transverse stiffness modulus of the masonry determined at the moment of first cracking $D_{\text {cr }}$ did not change considerably with increasing stress $\sigma_{c}$; 
- The compressive stress $\sigma_{\mathrm{c}}$ increased the transverse stiffness of the ceramic brick masonry $D_{\mathrm{i}}$ compared to the stiffness of the masonry determined at $\sigma_{\mathrm{c}}=0$ by 30 to $45 \%$. No such relation was observed in the case of walls made of AAC blocks.

\section{References}

[1] Piekarczyk A., "Shear stiffness of solid clay brick wallets sheared perpendicularly to the masonry bed joints", Procedia Engineering, vol. 161, 2016, pp. 1064-1069. https://doi.org/10.1016/j. proeng.2016.08.849

[2] Piekarczyk A., "Uszkodzenia i naprawy niekonstrukcyjnych elementów budynków", in $X X X$ Jubileuszowe Ogólnopolskie Warsztaty Pracy Projektanta Konstrukcji. Polski Związek Inżynierów i Techników Budownictwa. Oddział w Bielsku-Białej, vol. 3, Szczyrk, 2015, pp. 233-290.

[3] Piekarczyk A., "Shear modulus and non-dilatational strains of unreinforced and reinforced clay brick masonry", in $8^{\text {th }}$ International Masonry Conference, Dresden, 2010, pp. 315-324.

[4] Drobiec Ł., "Przyczyny uszkodzeń murów", in XXII Ogólnopolska Konferencja Warsztat Pracy Projektanta Konstrukcji. Polski Związek Inżynierów i Techników Budownictwa. Oddział w Bielsku-Białej, vol. 1, Szczyrk, 2007.

[5] Kubica J., Niezbrojone ściany murowane poddane odksztatceniom postaciowym wywołanym nierównomiernymi pionowymi przemieszczeniami podłoża. Wydawnictwo Politechniki Śląskiej, Gliwice 2003.

[6] Małyszko L., Orłowicz R., Konstrukcje murowe. Zarysowania i naprawy. Wydawnictwo Uniwersytetu Warmińsko-Mazurskiego w Olsztynie, Olsztyn 2000

[7] Masłowski E., Spiżewska D., Wzmacnianie konstrukcji budowlanych. Wydawnictwo „Arkady”, Warszawa 2002.

[8] Rudziński L., Konstrukcje murowe. Remonty i wzmocnienia. Wydawnictwo Politechniki Świętokrzyskiej, Kielce 2006.

[9] Stawski B., Konstrukcje murowe. Naprawy i wzmocnienia. Polcen Sp. z o.o., Warszawa 2014.

[10] Piekarczyk A., "Comparative investigations of unreinforced and reinforced masonry walls subjected to vertical shearing", in II International Scientific Conference - Quality and Reliability in Building Industry, Levoča, 2001, pp. 424-429.

[11] Piekarczyk A., Kubica J., "Capacity and deformability of vertically sheared clay brick masonry with horizontal reinforcement", in Proceedings of the British Masonry Society. Proceedings of the Sixth International Masonry Conference, Proceedings No. 9, London, 2002, pp. 386-391.

[12] Jasiński R., Piekarczyk A., "Cracking of clay brick masonry wallets sheared parallel and perpendicular to the bed joints - a trial of the problem description", in III International Scientific Conference - Quality and Reliability in Building Industry, Levoča, 2003, pp. 244-250.

[13] Jasiński R., Piekarczyk A., "Próba opisu zjawiska cinania w kierunku równoległym i prostopadłym do spoin wspornych niezbrojonych murów ceglanych", in XLIX Konferencja Naukowa Komitetu Inżynierii Lądowej i Wodnej PAN i Komitetu Nauki PZITB, Warszawa - Krynica, 2003, vol. 4, pp. 139-147.

[14] Kubica J., Piekarczyk A., "Tests of vertically sheared clay brick masonry walls with and without bed joint reinforcement", in Proceedings of $13^{\text {th }} I B^{2} M a C$, Amsterdam, 2004, pp. 191-200.

[15] Piekarczyk A., Nośność i odkształcalność zbrojonych ścian murowych poddanych ścinaniu w kierunku pionowym. Politechnika Śląska [praca doktorska], Gliwice, 2005.

[16] Kubica J., "Reinforced masonry shear walls - application, design and research problems", in Analytical models and new concepts in concrete and masonry structures AMCM'2008, $6^{\text {th }}$ International Conference, Łódź, 2008, pp. 43-57.

[17] Kubica J., Piekarczyk A., Investigations of reinforced (with "Murfor" reinforcement situated in bed joints) masonry walls made of AAC blocks "Ytong" type subjected to vertical shearing. Chapter 4. 
Main investigations - masonry wallettes subjected to vertical shearing. Research report NB-227/ RB-8/2008. Silesian University of Technology, Gliwice 2008.

[18] Kubica J., "In-plane sheared unreinforced masonry wallettes - proposition of failure criterion", in Proceedings of $15^{\text {th }} I B^{2} M a C$, Florianópolis, 2012, pp. 191-200.

[19] Drobiec Ł., Jasiński R., Piekarczyk A., Konstrukcje murowe wedtug Eurokodu 6 i norm zwiazanych. PWN, vol. 1, Warszawa, 2013.

[20] Kubica J., "Size and shape effect of test specimens on shear of clay brick and AAC block masonry - a comparative study" in $9^{\text {th }}$ International Masonry Conference, Guimaraes, 2014, p. 192.

[21] Kubica J., "Unreinforced clay brick masonry wallettes sheared perpendicular or parallel to the bed joints - a comparative study", in $16^{\text {th }}$ International Brick and Block Masonry Conference. Trends, innovations and challenges. CRC Press-Taylor \& Francis Group, Padova, 2016, pp. 1683-1690.

[22] Piekarczyk A., "The Influence of Compressive Stress on the Load-Bearing Capacity of Masonry Subjected to Vertical Displacements", in $3^{\text {rd }}$ World Multidisciplinary Civil Engineering -Architecture - Urban Planning Symposium, WMCAUS 2018, IOP Conference Series: Science and Engineering, vol. 471, Prague, 2019.

[23] Lurati F., Graf H., Thürlimann B., Experimental determination of the strength parameters of concrete masonry, Report No 8401-2. Institute of Structural Engineering, Zürich 1990.

[24] Raijmakers T. M. J., Vermeltfoort A. J., Deformation controlled tests in masonry shear walls, Report B-92-1156. TNO-Bouw, Delft 1992.

[25] Tsui T. P., “A preliminary investigation of the vertical shear strength of brick masonry", in $6^{\text {th }}$ International Brick/Block Masonry Conference, Rome, 1982, pp. 33-44.

[26] PN-EN 772-1 Metody badań elementów murowych. Część 1: Określenie wytrzymałości na ściskanie.

[27] PN-EN 998-2 Wymagania dotyczące zapraw do murów. Część 2: Zaprawa murarska.

[28] PN-EN 1996-1-1 Eurokod 6. Projektowanie konstrukcji murowych. Część 1-1: Reguły ogólne dla zbrojonych i niezbrojonych konstrukcji murowych. 
